\title{
Oestradiol decreases rat apolipoprotein AI transcription via promoter site $\mathrm{B}$
}

\section{A H Taylor, A E Fox-Robichaud ${ }^{1}$, C Egan ${ }^{1}$, J Dionne ${ }^{1}$, D E Lawless ${ }^{1}$, J Raymond $^{1}$, J Romney ${ }^{1}$ and N C W Wong ${ }^{1}$}

Gynaecology Research Group, Department of Obstetrics and Gynaecology, Faculty of Medicine and Biological Sciences, University of Leicester, PO Box 65, Leicester LE2 7LX, UK

${ }^{1}$ Endocrine Research Group, Departments of Medicine and Biochemistry \& Molecular Biology, the Faculty of Medicine, University of Calgary, Calgary, Alberta, Canada

(Requests for offprints should be addressed to N C W Wong, Faculty of Medicine, Departments of Medicine and Biochemistry \& Molecular Biology, Health Sciences Center, 3330 Hospital Drive NW, Calgary, Alberta, Canada, T2N 4N1; Email: ncwwong@ucalgary.ca)

\begin{abstract}
Oestrogens protect against ischaemic heart disease in the post-menopausal female by increasing serum concentrations of apolipoprotein (apo) AI and the abundance of high-density lipoprotein particles. In men and experimental male animals, the administration of oestrogen has variable effects on apo AI expression. As the major mode of oestrogen action on target genes involves regulating promoter activity and hence transcription, oestrogen is expected to alter transcription of the $a p o A I$ gene. To test this hypothesis, the effect of $17 \beta$-oestradiol $\left(\mathrm{E}_{2}\right)$, on rat apo AI promoter activity in male hepatoma HuH-7 cells, was tested by cotransfecting a reporter template, pAI.474.CAT containing -474 to -7 of the rat apo AI promoter and an oestrogen receptor (ER) expression vector, pCMV-ER. Transfected cells exposed to $\mathrm{E}_{2}$ showed a dose-dependent decrease in chloramphenicol acetyltransferase (CAT)-activity, with a maximum $91 \pm 1 \cdot 5 \%$ reduction at $1 \mu \mathrm{M} \mathrm{E}_{2}$. Deletional analysis of the promoter localized the inhibitory effect of ER and $\mathrm{E}_{2}$ to site $\mathrm{B}(-170$ to -144$)$ with an adjacent $5^{\prime}$
\end{abstract}

contiguous motif, site $\mathrm{S}(-186$ to -171$)$ acting as an amplifier. HuH-7 cell nuclear extracts showed binding activities with both sites $\mathrm{S}$ and $\mathrm{B}$, but recombinant human ER did not. Furthermore, nuclear extracts from $\mathrm{E}_{2}$-treated $\mathrm{HuH}-7$ cells showed weaker binding activity to site $\mathrm{B}$, but not to site S. In summary, the inhibitory effect of ER and $\mathrm{E}_{2}$ on rat apo $A I$ gene activity is mediated by a promoter element, site $B$. This inhibitory effect arises from a mechanism that does not involve direct ER binding to the B-element. The conclusion that $\mathrm{E}_{2}$ inhibits apo $A I$ transcription was confirmed in vivo. Treatment of male adult Sprague-Dawley rats with up to $200 \mu \mathrm{g} \mathrm{E}_{2}$ for 7 days decreased apo AI protein and hepatic mRNA by $72 \pm 21 \%$ and $68 \pm 1 \cdot 4 \%$ respectively. Results of 'run-on' transcription of the apo $A I$ gene in isolated hepatic nuclei showed a $55 \%$ decrease in hormone-treated male rats. These findings suggest that $\mathrm{E}_{2}$ exerts primarily an inhibitory effect within male hepatic nuclei.

Fournal of Molecular Endocrinology (2000) 25, 207-219

\section{INTRODUCTION}

Cardiovascular disease (CVD) is the leading cause of premature death of men and women in developed countries. Although death rates from CVD are similar, at $46 \%$ and $52 \%$ in men and women, the major difference is that the peak incidence in women occurs 10 years later than in men (Barter \& Rye 1996). The protection afforded to premenopausal women is in large part due to the beneficial effects of endogenous oestrogens. Oestrogen deficiency, caused by surgical or natural menopause, increases the risk of CVD in women by threefold (Barrett-Connor \& Bush 1991). Furthermore, epidemiological studies suggest that oestrogen replacement therapy in postmenopausal women reduces the risk of CVD by up to 50\% (Bush 1990, Stampfer \& Colditz 1991). In women with prior myocardial infarction, the benefit of hormone replacement may be as much as a $90 \%$ reduction 
in CVD risk (Sullivan et al. 1990). The precise mechanisms underlying the cardioprotective action of oestrogens are unknown. Although the mechanism is most probably multifactorial (Shewmon 1994), a major reduction in CVD risk is attributed to the effects of oestrogen on the metabolism of apolipoprotein (apo) AI and high-density lipoprotein (HDL) and low-density lipoprotein (LDL) particles (Bush et al. 1987).

Previous studies demonstrated that pre- or postmenopausal women treated with exogenous oestrogens have an increased abundance of apo AI and HDL (Walsh et al. 1991). However, oestrogen does not appear to augment the concentrations of apo AI and HDL in males and thus does not appear to protect individuals from CVD. Studies detailing the effect of oestrogens in males have shown contradictory findings. For example, male patients with prostate cancer or those undergoing sexchange procedures who are treated with exogenous oestrogen have a greater risk of developing new myocardial infarctions (Fortin et al. 1984, Henriksson et al. 1987). Similarly, hyperoestrogenaemia in males attributed to increased hepatic conversion of testosterone as a result of cigarette smoking, alcohol intake, diabetes, or drug abuse carried a greater risk of CVD, in some (Morgan 1982, Klaiber et al. 1984, Phillips 1984, Glazer 1991), but not all studies (Ruebner et al. 1961). In contrast, other data suggest that oestrogens reduce the risk of CVD in males (Marmorston et al. 1960, Farhat et al. 1996). In addition, newborn animals, pre-pubertal boys and men with cirrhosis of the liver-that is, those males with high concentrations of oestrogens but low testosterone have reduced prevalence of CVD (Fangman \& Hellwig 1947, Neufeld et al. 1962, Sukurai et al. 1978, O'Kane et al. 1997). In experimental animals the data are equally confusing, various studies showing decreased (Weinstein et al. 1986, Srivastava et al. 1993, Zou \& Ing 1998), increased (Seishima et al. 1991) and no (Srivastava et al. 1997) oestrogenic effect on apo AI expression in the male.

The preceding data portray an unclear picture of the cardioprotective role of oestrogen in normal intact males. As oestrogens and other steroid hormones increase apo AI expression in the female through activation of the apo AI promoter, we examined the effect of $17 \beta$-oestradiol $\left(E_{2}\right)$ on apo AI promoter activity in males. The following studies show that $\mathrm{E}_{2}$ inhibits apo $A I$ gene transcription via a cis-acting promoter motif designated site $\mathrm{B}$. In addition, $\mathrm{E}_{2}$ increases female, but decreases male, rat serum apo AI protein concentrations.

\section{MATERIALS AND METHODS}

\section{Materials}

The rat apo AI cDNA, rat apo AI antibody, wild-type, mutant and site-specific pAI.CAT constructs have been described previously (Romney et al. 1992, Taylor et al. 1996a). Both the human ribosomal RNA (Sylvester et al. 1986) and pRSV- $\beta$-galalactosidase plasmids were gifts (Chan et al. 1993). The p5'S.CAT, p5'S2.CAT and p5'S3.CAT constructs were created by ligating one, two or three copies, respectively of site S (gatccGCAGCCCCCGCAGCTTCCTGTTg, Gibco BRL, Burlington, Ontario, Canada) into the SmaI site of pGEM-CAT.5' (Romney et al. 1992). The SB.CAT construct was created by annealing the antisense strand of site $\mathrm{S}$ with site $\mathrm{B}$ (gatccAGGCTAGGCAAACAGAGTGGGCAAACAGGAAc), followed by a 'fill in' reaction with the Klenow fragment of DNA polymerase I. The product was then cloned into the SmaI site of pGEM-CAT. $5^{\prime}$ in the correct orientation as a monomer. Complementary strands of both sites $\mathrm{S}$ and $\mathrm{B}$ with protruding EcoRI ends and an oestrogen response element (ERE; aattCGGTCACTGTGACCGaatt) were purchased from Integrated DNA Technologies, Inc., Coralville, IA, USA, for use in electrophoretic mobility shift assays (EMSA). Human recombinant oestrogen receptor protein $(\mathrm{ER} \alpha)$ was purchased from Affinity Bioreagents, Inc., Golden, CO, USA. The pCMV-ER was a kind gift from Dr R Misicek, University of New York.

\section{Cell culture and transfection}

Male human fetal hepatoma HuH-7 cells were cultured in serum-free RPMI-ISE medium, as previously described (Nakabyashi et al. 1989). This medium contains $1.4 \times 10^{-5} \mathrm{M}$ phenol red but, to observe the effect of exogenous $\mathrm{E}_{2}$, cells are cultured in medium that lacks phenol red because this compound is weakly oestrogenic (Bindal et al. 1988). In the absence of phenol red, HuH-7 cells rapidly die (authors' unpublished observations). Therefore, for $\mathrm{E}_{2}$ studies, HuH-7 cells were subcultured to $25 \mathrm{~cm}^{2}$ flasks for $48 \mathrm{~h}$ in RPMI-ISE medium and then transferred to medium containing a lower concentration of phenol red $\left(7 \times 10^{-7} \mathrm{M}\right)$ for a further $24 \mathrm{~h}$ before transfection in the same medium. After transfection (Romney et al. 1992), cells were exposed to $\mathrm{E}_{2}$ for $24 \mathrm{~h}$ and then harvested (Taylor et al. 1996a). Cell lysate was assayed for $\beta$ galactosidase and chloramphenicol acetyltransferase (CAT) activities as described elsewhere (Taylor et al. 
1996b). The CAT activities were corrected for protein concentration, $\beta$-galactosidase activity and assay duration.

\section{Electrophoretic mobility shift assay}

The ERE, site $\mathrm{S}$ and site $\mathrm{B}$ oligomers were labelled with $\left[{ }^{32} \mathrm{P}\right] \alpha-\mathrm{dCTP}$ or $\left[{ }^{32} \mathrm{P}\right] \alpha-\mathrm{dATP}$ in the presence of the Klenow fragment of DNA polymerase I and the radiolabelled oligomer purified by size-exclusion chromatography (Maniatis et al. 1983). Nuclear extracts from control HuH-7 cells or those transfected with pCMV-ER (Reese \& Katzenellenbogen 1991) were prepared using an established method (Ausubel et al. 1995). The EMSA studies were performed as described previously (Taylor et al. 1996a), but with the method modified so that concentrations of radiolabelled oligomer, nuclear protein, polydI.dC and time of electrophoresis were optimized for each probe. Reactions to test the binding of ER to ERE contained $5 \times 10^{-6} \mathrm{M} \mathrm{E}_{2}$. Protein-DNA complexes were visualized by autoradiography using Kodak Ektascan EMC-1 or Biomax MR films. Competition analysis was performed in the presence of 100-fold molar excess of specific or non-specific oligonucleotides.

\section{Animals, serum protein and RNA preparation}

Sprague-Dawley rats (150-200 g) from the CharlesRiver Breeding Company, St Constance, Quebec, Canada were fed a diet of rat chow (Purina), with water available ad libitum, and housed under conditions of 12-h light-12-h darkness. 17 $\beta$ Oestradiol (Sigma-Aldrich, Oakville, Ontario, Canada) was dissolved in $95 \%$ ethanol before further dilution with propan-1,2-diol to give a final concentration of up to $200 \mu \mathrm{g} / 100 \mu \mathrm{l}$. Control animals received $0.9 \%$ saline and diluent control animals were injected with vehicle $(15 \%$ ethanol and $85 \%$ propan-1,2-diol) alone. The animals were then injected subcutaneously with saline, diluent or $\mathrm{E}_{2}$ (up to $200 \mu \mathrm{g} /$ day) for 7 days. On the eighth day, the rats were killed under light ether anaesthesia (Chan et al. 1993) and the sera prepared by centrifugation at $800 \mathrm{~g}$ for $10 \mathrm{~min}$ at $4{ }^{\circ} \mathrm{C}$ and stored frozen at $-80^{\circ} \mathrm{C}$ until required for western analyses. Approximately $500 \mathrm{mg}$ freshly excised liver were snap-frozen for RNA extraction using the guanidinium isothiocyanate-phenol-chloroform method (Promega, Madison, WI, USA). The remainder of the fresh liver was used to prepare intact nuclei for in vitro transcription and nuclear proteins for EMSA studies.

\section{Northern analysis}

Total hepatic RNA (10-40 $\mu \mathrm{g})$ was analysed by northern blot analysis (Sambrooke et al. 1989). The $28 \mathrm{~S}$ and $18 \mathrm{~S}$ rRNA were visualized by staining with ethidium bromide to ensure that the RNA was intact, and equal amounts were loaded. Contents of the gel were blotted to Zetabind membrane (AMF Cuno Inc., Meriden, CT, USA) and probed with radiolabelled rat apo AI cDNA (Taylor et al. 1996a). Apo AI mRNA abundance was determined by video-assisted densitometry and normalized to the density of the $18 \mathrm{~S}$ RNA obtained from a photographic negative of the ethidium-bromidestained gel.

\section{Preparation of nuclei and nuclear 'run-on'}

Preparation of rat liver nuclei and their use in the in vitro transcription assay were as described previously (Taylor et al. 1996a). Each labelling reaction contained $1 \cdot 3-4 \cdot 8 \times 10^{7}$ nuclei. Blots were hybridized at $65^{\circ} \mathrm{C}$ with $3 \cdot 3-4 \cdot 3 \times 10^{6}$ c.p.m. 'input' RNA. Membranes were washed at high stringency and signal detected by autoradiography using Kodak XAR-5 film for $2-4$ days at $-80^{\circ} \mathrm{C}$. The hybridization signal was assessed by videoassisted densitometry. These values were expressed relative to rRNA standards and then normalized for both 'input' RNA per hybridization and the number of nuclei per assay.

\section{Statistical analysis}

Data are presented as mean \pm S.D. and significance determined by either unpaired Student's $t$-test or one-way analysis of variance (ANOVA) using the least significance difference test provided in the Clinstat software package (Bland 1990).

\section{RESULTS}

\section{Site $B$ mediates the repressive effects of $E_{2}$}

To determine whether $\mathrm{E}_{2}$ inhibits apo AI promoter activity, we measured activity of a construct, pAI.474.CAT containing the -474 to $-7 \mathrm{bp}$ fragment of rat apo AI DNA in a male human hepatoma cell line, $\mathrm{HuH}-7$, co-transfected with an ER expression vector, pCMV-ER. Subsequent exposure of these cells to $\mathrm{E}_{2}$ caused a dosedependent decrease in promoter activity with a maximal $91 \%$ reduction at a hormone concentration of $5 \times 10^{-6} \mathrm{M}$ (Fig. 1).

To locate the motif that mediated the effects of $\mathrm{E}_{2}$, we assayed the activity of deletional constructs 


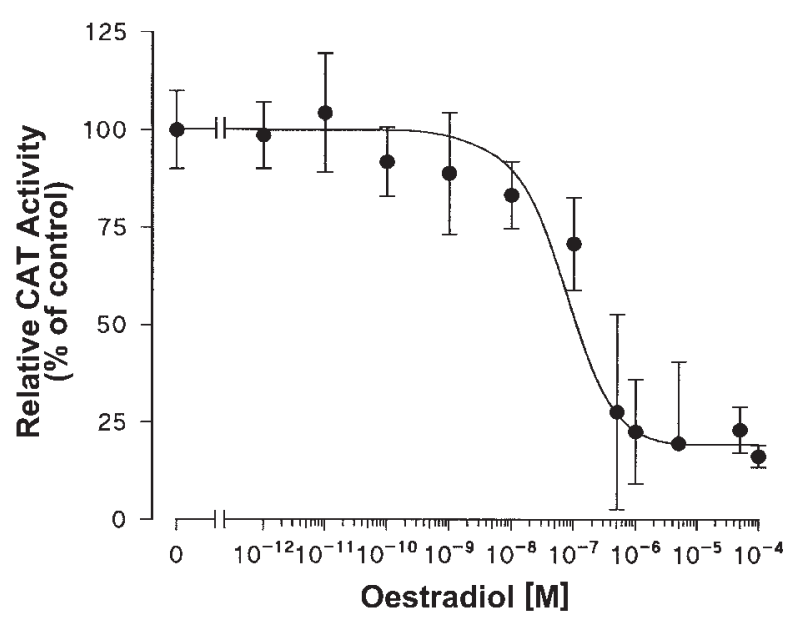

FIGURE 1. Dose-dependent decrease in apo $A I$ transcription by oestrogen. HuH-7 cells were cotransfected with pAI.474.CAT, $\beta$-galactosidase, and pCMV-ER and treated with the indicated doses of $E_{2}$ for $24 \mathrm{~h}$. CAT activity in the cells was normalized against $\beta$-galactosidase activity. The data are expressed relative to untreated cells. Values shown are means \pm S.D. for at least six experiments performed in duplicate. containing smaller amounts of the promoter (schematic map; Fig. 2A) in the presence of pCMV-ER and $10^{-6} \mathrm{M} \mathrm{E}_{2}$. Removal of the DNA between -474 to $-187 \mathrm{bp}$ did not significantly alter the inhibitory actions of $\mathrm{E}_{2}$ (pAI.186.CAT, Fig. 2B). However, most of the inhibitory effect of $\mathrm{E}_{2}$ was lost in constructs lacking -474 to $-170 \mathrm{bp}$ or $-144 \mathrm{bp} \quad(60 \pm 7 \%$ and $25 \pm 2 \%$ respectively $)$ compared with control. Together these findings show that the cis-acting element spanning -170 to $-145 \mathrm{bp}$ mediates a dominant role in the inhibitory actions of $\mathrm{E}_{2}$, and that an adjacent element, -186 to $-171 \mathrm{bp}$, has a minor role. These two elements correspond to two motifs, $\mathrm{B}$ and $\mathrm{S}$, that we described previously (Taylor et al. 1996a). A minimal promoter, -46 to $-7 \mathrm{bp}$, was nonresponsive to $\mathrm{E}_{2}$ (pAI.46.CAT; Fig. 2). These observations suggest that the inhibitory effect of $\mathrm{E}_{2}$ is mediated by site $B$.

Next we examined the ability of site B to transmit the inhibitory actions of $\mathrm{E}_{2}$. For these studies we created a template, $\mathrm{p} 5{ }^{\prime} \mathrm{B}$.CAT, containing duplicate $\mathrm{B}$ sites placed in front of the heterologous

A

B
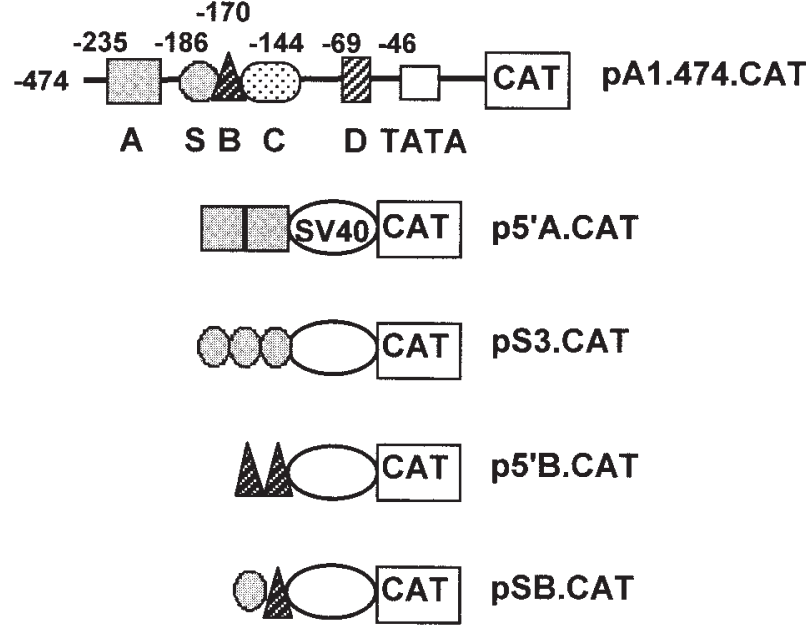

P5'B.CAT

PSB.CAT

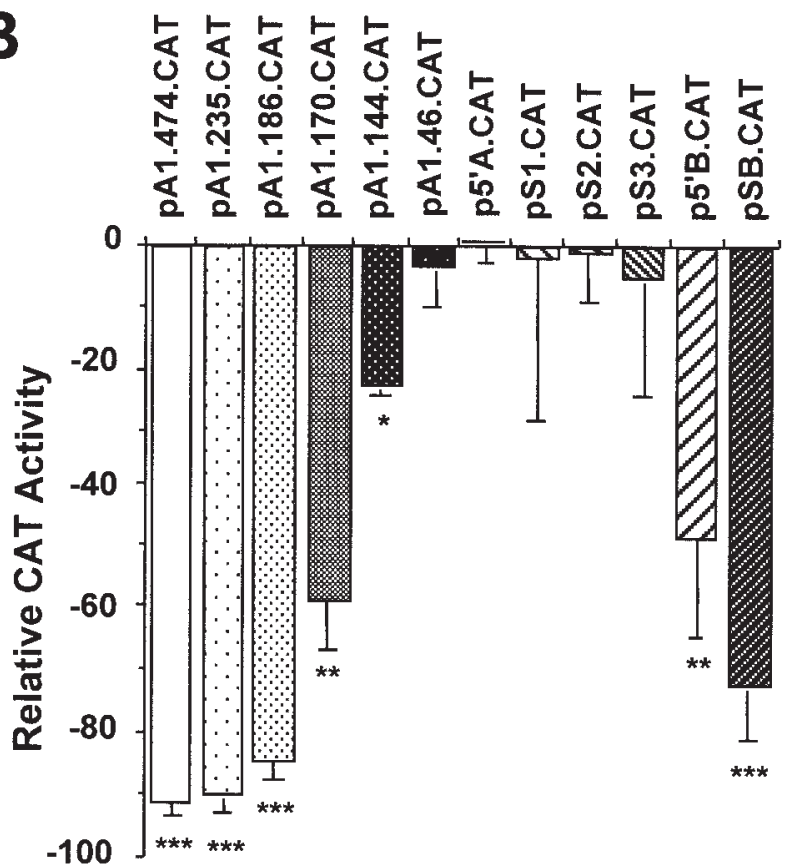

$-100$

FIGURE 2. Apo AI site B contains the oestrogen-responsive sequence. (A) Schematic diagram showing the rat apo AI promoter-CAT constructs used in the transfection studies. The various geometric shapes represent the cis-acting elements of the rat apo AI promoter. The boxes labelled SV40 and CAT are the heterologous SV40 promoter sequence and the $C A T$ reporter gene respectively. Numbering is relative to the transcription start site. (B) HuH-7 cells were transfected with the constructs noted on top, $\beta$-galactosidase, and pCMV-ER and treated with $10^{-6} \mathrm{M} \mathrm{E}_{2}$ for $24 \mathrm{~h}$. Cellular proteins were assayed for CAT activity and corrected for $\beta$-galactosidase activity. The data are expressed relative to cells containing the same deletional construct without pCMV-ER (the abscissa). Values are means \pm S.D. for at least three experiments performed in triplicate. $* P<0 \cdot 05, * * P<0 \cdot 01, * * * P<0 \cdot 001$, one-way ANOVA compared with untreated control. 
SV40 promoter that is fused to the $C A T$-gene (Fig. 2A). CAT activity in $\mathrm{E}_{2}$-treated $\mathrm{HuH}-7$ cells co-transfected with $\mathrm{p} 5^{\prime} \mathrm{B} . \mathrm{CAT}$ and $\mathrm{pCMV}$-ER was decreased by $49 \pm 13 \%$ (p5'B.CAT, Fig. 2). The specificity of this effect to site $\mathrm{B}$ was demonstrated in the study of similar constructs, pS1.CAT, pS2.CAT, pS3.CAT and p5'A.CAT, that contained one, two or three copies of site $\mathrm{S}$ and duplicate site A respectively. $E_{2}$ had no effect on activities of these constructs (Fig. 2).

\section{Potential roles of site $\mathrm{S}$}

To examine the potential roles of site $\mathrm{S}(-186$ to $-171 \mathrm{bp}$ ), we created pSB.CAT, which contains sites $\mathrm{S}$ and $\mathrm{B}$ fused in tandem to the SV40 promoter $5^{\prime}$ to the $C A T$-gene (Fig. 2A). $\mathrm{E}_{2}$ inhibited the activity of this construct by $72 \cdot 4 \%$ (Fig. 2B). This level of repression was more pronounced than the sum of that of either site S (pS1.CAT; 2.3\% reduction) or site $\mathrm{B}$ alone (pAI.170.CAT; $58.4 \%$ reduction). Together, these data suggest that $\mathrm{E}_{2}$ acts through site $\mathrm{B}$ and that site $\mathrm{S}$ amplifies or augments the inhibitory actions of $\mathrm{E}_{2}$ through site B.

\section{$E_{2}$ receptor does not bind to sites $S$ and $B$}

In an attempt to define the mechanism by which $\mathrm{E}_{2}$ inhibits the transcription of the rat apo AI promoter, EMSA were performed with purified human recombinant $\mathrm{ER} \alpha(\mathrm{hER} \alpha)$ to $\left[{ }^{32} \mathrm{P}\right] \mathrm{ERE}$. Purified hER $\alpha$ bound to $\left[{ }^{32} \mathrm{P}\right]$ ERE (lane 1, Fig. 3). The addition of 100-fold M excess unlabelled ERE blocked the formation of the ER-ERE complex, but excess site $\mathrm{S}$ or B (lanes 2-4 respectively, Fig. 3A) had no effect. These findings indicate that $\mathrm{hER} \alpha$ binds to the ERE, but not to sites $\mathrm{S}$ or $\mathrm{B}$.

\section{Nuclear protein binding to sites $\mathrm{S}$ and $\mathrm{B}$}

Next we examined the ability of HuH-7 nuclear proteins to bind sites $\mathrm{S}$ and $\mathrm{B}$ (Fig. 3B). Incubation of nuclear extracts with radiolabelled site $\mathrm{S}$ revealed the presence of at least three binding activities (lane 2, Fig. 3B). These activities were unaffected by the treatment of cells with $\mathrm{E}_{2}$ (lane 3, Fig. 3B). In contrast, the pattern of nuclear protein binding to site B DNA was more complex (lanes 4-8, Fig. 3B). Nuclear proteins from HuH-7 cells had at least five site $\mathrm{B}$ binding activities. The intensities of the three complexes with the slowest mobilities (asterisks and arrow) were less abundant in $\mathrm{E}_{2}$-treated cells transfected with ER (compare lanes 5 and 6 with 7 and 8 , Fig. 3B). In addition, there was a slight increase in intensity of the second most mobile band in extracts from $\mathrm{E}_{2}$-treated cells (Fig. $3 \mathrm{~B}$ ), but this complex represented non-specific binding. Only a single complex was specific in competition analysis (arrow, Fig. 3C). The abundance of this complex was decreased in response to $\mathrm{E}_{2}$. The most mobile band (denoted by a dot in Fig. 3B) remained unchanged. These data show that $\mathrm{E}_{2}$ decreases specific site $\mathrm{B}$ binding activity.

\section{Mutation of HNF3 elements in site B abolish actions of ER}

Site B in the apo AI promoter is comprised of direct repeats, with two HNF-3 motifs of 9 bp separated by a 4 bp spacer (Fig. 4A). To determine whether this element mediates the repressive actions of ER and $\mathrm{E}_{2}$, we used a reporter template, BCD.CAT (Fig. 4A). The activity of this template was similar to that of pAI.170.CAT in the absence or presence of pCMV-ER and $\mathrm{E}_{2}$ (compare Fig. 4B and Fig. 2). CAT activity in cells transfected with BCD.CAT alone was not significantly different from control after treatment with $\mathrm{E}_{2}$. However, in the presence of ER there was a $89 \%$ reduction in CAT activity from $7 \cdot 85 \%$ to $0 \cdot 85 \%$ CAT conversion/ $\mu$ g protein/h (Fig. $4 \mathrm{~B})$. An additional $45 \%$ reduction was evident in the presence of exogenous $\mathrm{E}_{2}$ (from $0.85 \%$ to $0.473 \%$ CAT conversion/ $\mu$ g protein/h). The inset to Fig. 4B shows a western blot analysis of lysate from control cells or those transfected with pCMV-ER. ER was not detected in control cells, but is clearly evident in those containing the expression vector. This result supports the finding that $\mathrm{E}_{2}$ suppression of the reporter requires $\mathrm{ER}$.

Next, we used three templates containing mutations to the HNF-3 sites. First, we found that pA1.Bm1.CAT, which contained a mutation of the HNF-3 motif at the $5^{\prime}$ end of site $\mathrm{B}$, had a dramatic reduction in basal activity from $7 \cdot 85 \%$ to $0 \cdot 17 \%$ CAT conversion/ $/ \mathrm{g}$ protein/h (Fig. 4B). Despite this low expression, the activity of this construct was further reduced by $25 \%$ in the presence of ER (Fig. 4C). However, no further reduction was evident after the addition of $\mathrm{E}_{2}$. Another template, pAI.Bm2.CAT, containing a mutation of the HNF-3 motif at the $3^{\prime}$ end of site $B$, showed a similar reduction in basal activity and, like pA1.Bm1.CAT, it was no longer responsive to $E_{2}$ (Fig. 4C). These data confirm that the inhibitory action of ER requires an intact site B. In addition, the construct pAI.158.CAT - a template that lacks the $5^{\prime}$ HNF- 3 site - had very low basal CAT activity $(0 \cdot 47 \%$ CAT conversion $/ \mu \mathrm{g}$ protein $/ \mathrm{h})$ compared with BCD.CAT (Fig. 4B). However, the activity of this construct, which retains an unmodified $3^{\prime}$ HNF-3 site, was reduced by $28 \%$ in the presence of 
ER (Fig. 4C). Together, these mutants and deletion analyses show that intact $\mathrm{HNF}-3$ sites are required for $\mathrm{E}_{2}$ to exert its inhibitory actions in the presence of ER and the 3' HNF-3 motif alone appears capable of mediating the repressive actions of ER.

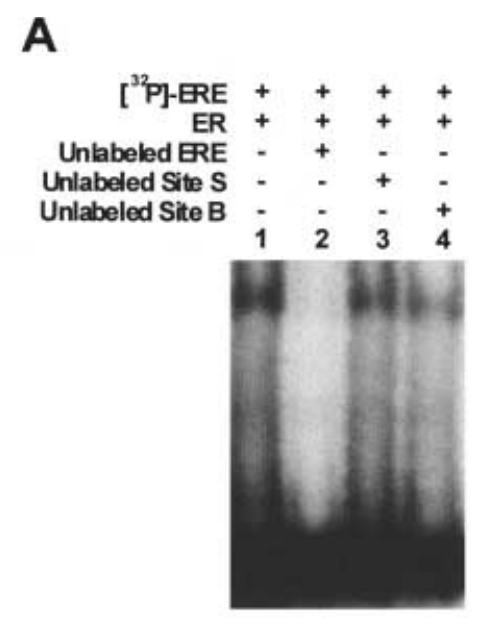

B

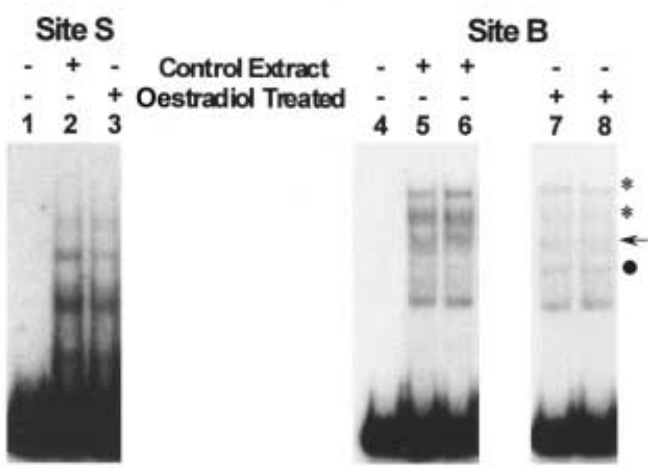

C

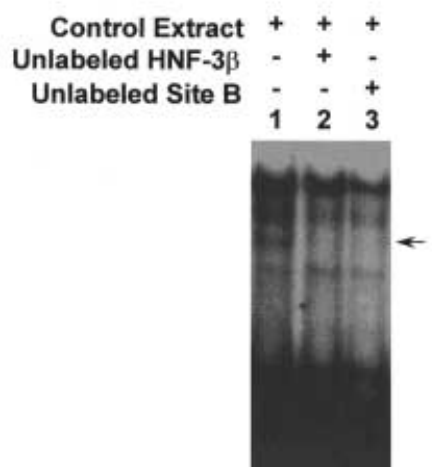

These data suggest that the HNF-3 sites have a critical role in mediating the actions of $\mathrm{E}_{2}$.

\section{$\mathrm{E}_{2}$ decreases apo $\mathrm{AI}$ abundance, expression and transcription}

As expected, administration of $\mathrm{E}_{2}$ to female rats produced a significant 2.9-fold up-regulation of serum apo AI concentrations (Fig. 5A, B). However, administration of $\mathrm{E}_{2}$ to male rats had the opposite effect on apo AI expression: male animals injected with $\mathrm{E}_{2}$ for 7 days had $72 \%$ less apo $\mathrm{AI}$ protein in serum (Fig. 5C, D) and a $68 \%$ lower hepatic mRNA content (Fig. 6A, B). Similarly, $\mathrm{E}_{2}$ also reduced the 'run-on' transcription rate of the gene by $55 \%$, from $12 \cdot 9 \pm 3 \cdot 1$ to $5 \cdot 8 \pm 0 \cdot 77 \mathrm{ng}$ RNA $/ 10^{6}$ nuclei/h (Fig. 6). However, the rate of albumin gene transcription was not significantly affected by hormone administration (Fig. 6D). These data suggest that $\mathrm{E}_{2}$ reduced male apo AI serum protein and hepatic mRNA levels via a reduction in transcription of the gene.

\section{DISCUSSION}

The major economic and social impact of CVD on members of our society makes this condition an important topic for biomedical research. Apo AI

FIGURE 3. EMSA of ER binding to ERE but not to apo AI sites $\mathrm{S}$ or B. (A) Purified human recombinant ER $\alpha$ protein was incubated with $\left[{ }^{32} \mathrm{P}\right]$-labelled ERE for 30 min in EMSA binding buffer (lane 1) supplemented with $5 \times 10^{-5} \mathrm{M} \mathrm{E}_{2}$. A 400-fold molar excess of unlabelled ERE (lane 2), site S (lane 3), or site B (lane 4) was added to the basic reaction mixture. Bound and free radioactivity were visualized as described in Materials and Methods. The autoradiogram is a representative of four separate experiments. (B) $\mathrm{E}_{2}$ decreases binding to site $\mathrm{B}$ but not site $\mathrm{S}$. Nuclear extracts from ER-containing HuH-7 cells treated with or without $\mathrm{E}_{2}$ were incubated with either $\left[{ }^{32} \mathrm{P}\right]$-labelled sites $\mathrm{S}$ (lanes 2 and 3 respectively) or B (lanes 5 and 6 , and 7 and 8 respectively) for $30 \mathrm{~min}$. DNA-protein complexes that were reduced after treatment with $\mathrm{E}_{2}$ are indicated by asterisks and an arrow. Non-specific complexes are indicated by asterisks or the dot. The autoradiogram is representative of three separate experiments. (C) Competition analysis. Site B binding activity in extracts from control cells is bound to radiolabeled DNA (lane 1) in the presence of 100-fold $\mathrm{M}$ excess unlabeled authentic HNF-3 $\beta$ (lane 2) or site B (lane 3) binding motif. Addition of excess non-specific DNA had no effect on intensity of the complexes (data not shown). The only specific complex is indicated by an arrow. 


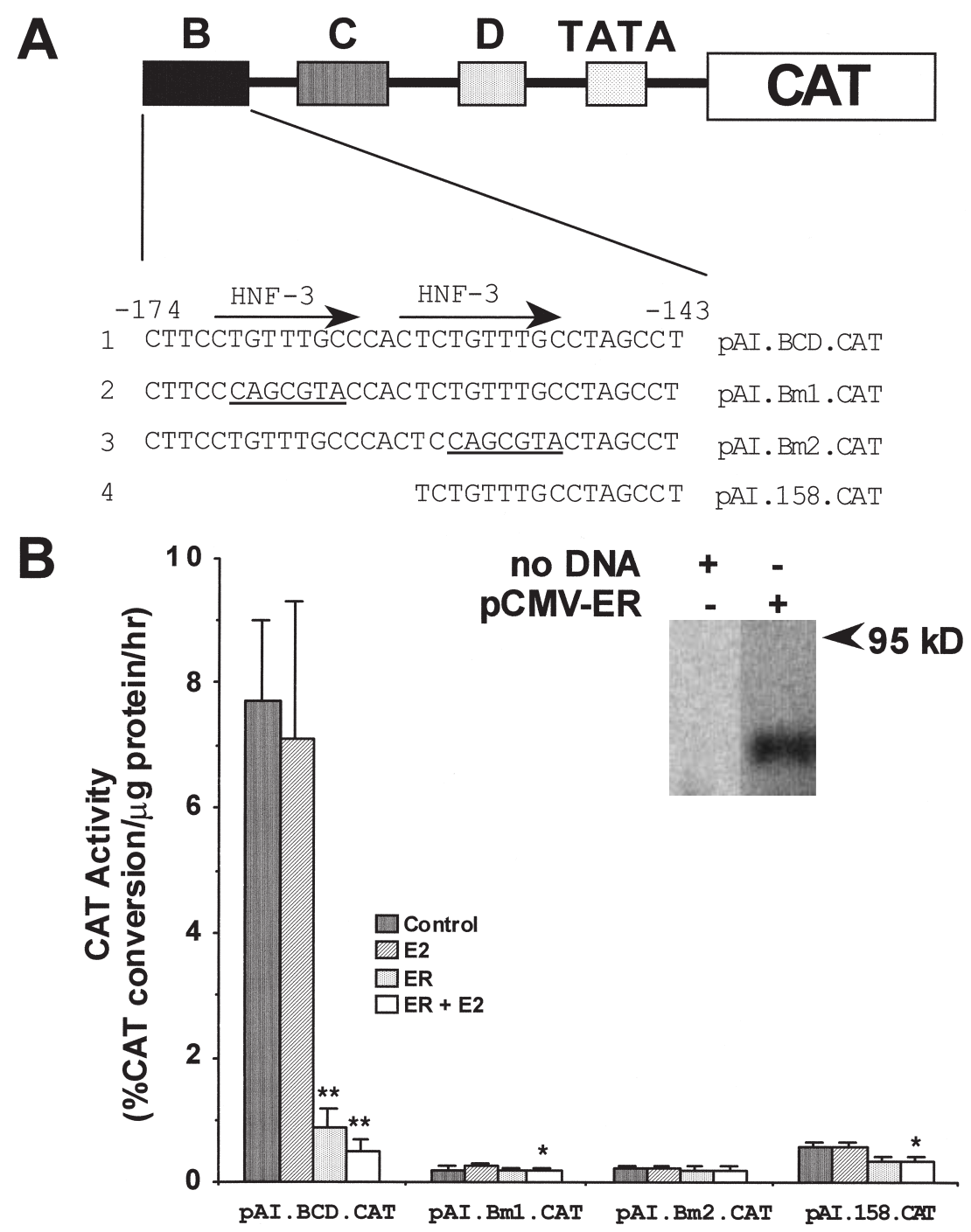

FIGURE 4. Mutation of HNF-3 sites in site B abolishes oestrogen responsiveness. (A) Schematic diagram and site $\mathrm{B}$ sequences showing the rat apo AI promoter-CAT constructs used in the transfection studies. HNF-3 sites are represented by the arrows and mutations are underlined. Numbering is relative to the transcription start site. (B) HuH-7 cells were transfected with wild-type (pAI.BCD.CAT), mutated (pAI.Bm1.CAT, pAI.Bm2.CAT), or deleted (pAI.158.CAT) pAI-CAT constructs. Parallel cultures were grown and treated with $10^{-6} \mathrm{M} \mathrm{E}_{2}$. Cells co-transfected with pCMV-ER were treated with vehicle and $10^{-6} \mathrm{M} \mathrm{E}_{2}$ for $24 \mathrm{~h}$. Cellular proteins were assayed for CAT activity and the data presented relative to pAI.BCD.CAT. Values are shown as means \pm S.D. from two experiments performed in triplicate. The insert shows levels of ER $\alpha$ as detected by western blot of lysates from cells that were non-transfected or transfected with pCMV-ER. ${ }^{*} P<0 \cdot 05$, $* * P<0 \cdot 01$; ANOVA with least significant difference test.

and HDL act as protectors against CVD by amelioration of hypercholesterolaemia via several mechanisms that decrease cholesterol serum concentrations (Kashyap 1998). Therefore, it seems reasonable to postulate that to increase rates of synthesis of serum apo AI would have beneficial effects on health. In order to work towards this goal, we have embarked on a detailed analysis of the apo 


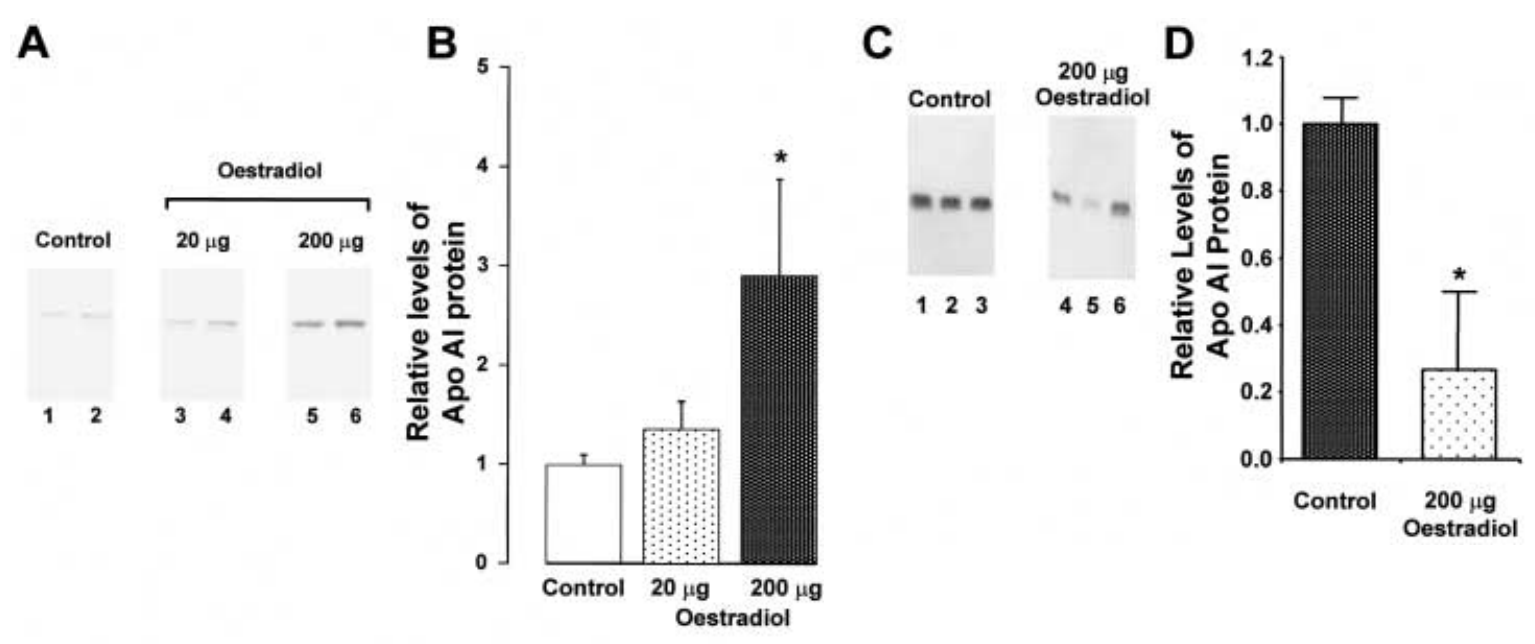

FIGURE 5. $\mathrm{E}_{2}$ increases female and decreases male apo AI serum protein concentrations. Representative western blot analysis of $1 \mu \mathrm{g}$ per lane total serum proteins from $(\mathrm{A})$ control $(n=4)$ and $\mathrm{E}_{2}$-treated $(n=4)$ female, and $(\mathrm{C})$ control $(n=12)$ and $\mathrm{E}_{2}$-treated $(n=18)$ male Sprague-Dawley rats. $(\mathrm{B}, \mathrm{D})$ Densitometric quantitation of the female and male data presented in (A) and (C) respectively. Data are presented as the mean \pm s.D.; $* P<0 \cdot 05$ (ANOVA).
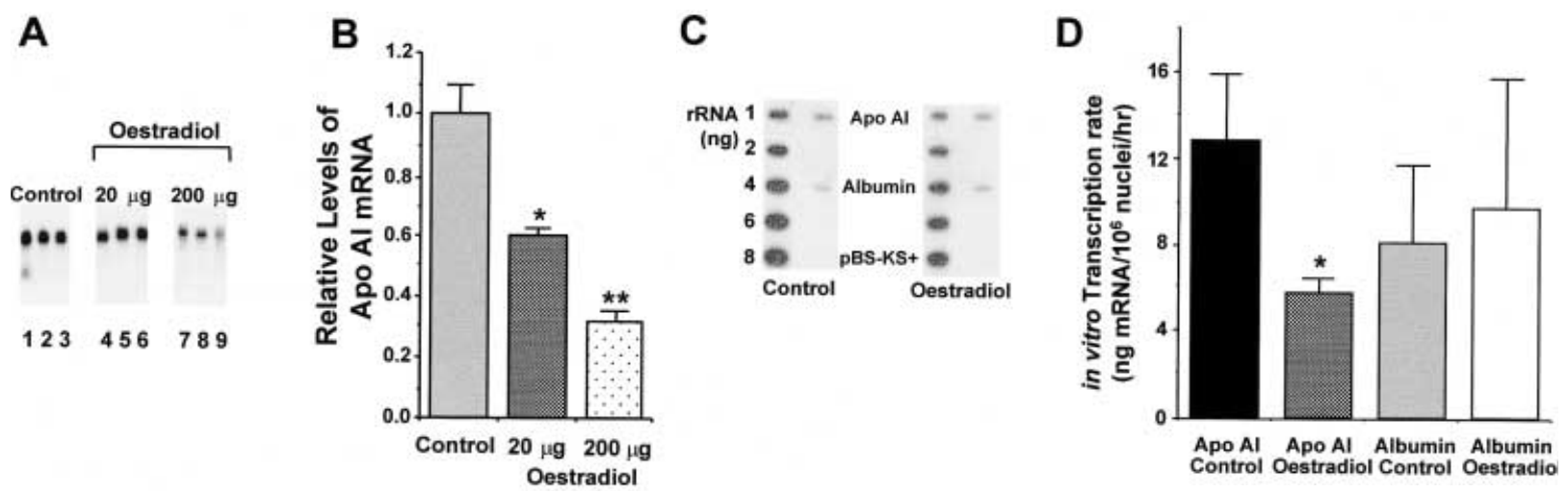

FIGURE 6. $\mathrm{E}_{2}$ decreases hepatic apo AI mRNA levels and 'run-on' transcription of rat apo AI gene. (A) Apo AI northern blot analysis of total hepatic RNA (10 $\mu \mathrm{g})$ from control (lanes 1-3) Sprague-Dawley male rats and male rats treated with either $20 \mu \mathrm{g}$ (lanes 4-6) or $200 \mu \mathrm{g}$ (lanes 7-9) of E2. (B) Densitometric quantitation of the signal from the control $(n=12)$, males treated with $20 \mu \mathrm{g}$ E2 $(n=6)$ and those treated with $200 \mu \mathrm{g}$ E2 $(n=9)$ shown in panel A. Data are the mean \pm S.D.; $* P<0 \cdot 05 ; * P<0 \cdot 01$ (Student's unpaired t-test). (C) Hepatic nuclei from control and $\mathrm{E}_{2}$-treated $(200 \mu \mathrm{g})$ male rats were incubated in the presence of $\left[{ }^{32} \mathrm{P}\right] \mathrm{UTP}$. RNA harvested from these nuclei was hybridized to mouse rRNA gene (1-8 ng), rat apo AI (1 $\mu \mathrm{g})$ and rat albumin $(1 \mu \mathrm{g})$ cDNAs and EcoRI fragment of pBS- $\mathrm{KS}^{+}$. Hybridized RNA was detected by autoradiography. Apo AI and albumin transcription rates were determined by video-assisted densitometry and then normalized to the rRNA standard curve signal values. The data were further corrected for 'input' RNA and the values shown are means \pm S.D. from three separate experiments per group. $* P<0 \cdot 05$, Student's $t$-test.

AI promoter. The clinical observation that $\mathrm{E}_{2}$ in women reduces their risk of developing CVD prompted us to investigate whether this beneficial effect can be extended to males, by examining effects of the hormone on the apo AI promoter. Results of these studies show that $\mathrm{E}_{2}$ decreases apo AI promoter activity in males.
In the initial transfection experiment with pAI.474.CAT and $E_{2}$, an inhibitory effect of $E_{2}$ was demonstrated and shown to be dependent on the dose of hormone in $\mathrm{HuH}-7$ cells, which are derived from a male liver (Fig. 1). Similar studies performed on the human apo AI promoter in HepG2 cells (also derived from a human male liver), 
co-transfected with a similar ER expression plasmid, showed similar dose-dependent decreases in apo AI promoter activity (Harnish et al. 1998). Maximal inhibition of reporter transcription from the human apo AI promoter in HepG2 cells was an order of magnitude lower than in the results presented here using a rat apo AI promoter construct $\left(5 \times 10^{-8} \mathrm{M}\right.$ compared with $5 \times 10^{-7} \mathrm{M}$ in HuH-7 cells). The difference in extent of inhibition by $E_{2}$ in these two sets of data may be due to differences in the nature of the human and rat promoters. Although these promoters share greater than $90 \%$ homology, there is a significant difference in their responses to many transcription factors, including ROR and PPAR (Vu-Dac 1997, Staels \& Auwerx 1998). However, although the human and rat apo AI promoter differ in response to some factors, in both HepG2 cells and $\mathrm{HuH}-7$ cells, the apo AI promoter activity is inhibited by $\mathrm{E}_{2}$.

The expression of oestrogen-responsive genes such as ovalbumin and $I G F-1$ are also regulated by $\mathrm{E}_{2}$ at the transcriptional level. In these cases, liganded ER interacts with ERE motifs in the promoter to decrease gene expression (Sanders \& McKnight 1988, McCarthy et al. 1997). Other genes such as the EGF receptor, the progesterone receptor and $E R$ itself are up-regulated at the transcriptional level via promoter-specific ERE motifs. However, an examination of the apo AI promoter DNA for consensus ERE motifs (GGTCAnnnTGACC), shows none to be present. As some $\mathrm{E}_{2}$-dependent genes lack consensus EREs, $\mathrm{E}_{2}$ action may also be mediated via non-genomic mechanisms or via other cis-acting elements. For example, $\mathrm{E}_{2}$ regulates gene transcription via $\mathrm{AP}-1$ and SP-1 sites (Cerillo et al. 1998, Xie et al. 1999) in which the liganded ER does not contact the DNA.

The lack of a consensus ERE in the rat apo $A I$ gene led us to perform deletional analysis of the rat apo AI promoter. The element that mediates the inhibitory actions of $\mathrm{E}_{2}$ is site $\mathrm{B}$. This conclusion comes from the fact that removing DNA spanning -186 to -145 bp caused the inhibitory effect of $E_{2}$ on promoter-CAT activity to lessen from $85 \%$ to $20 \%$. There are two cis-acting sites, which we have designated site $\mathrm{S}$ and site $\mathrm{B}$, in this fragment of the promoter. Removal of site $\mathrm{S}(-186$ to -171$)$ caused a $25 \%$ change in $\mathrm{E}_{2}$ effectiveness from $85 \%$ to $60 \%$, indicating that this portion of the fragment has a minor role in the actions of $E_{2}$. Further removal of site $\mathrm{B}(-170$ to -145$)$ caused a $40 \%$ change in $\mathrm{E}_{2}$ effectiveness, indicating that site $\mathrm{B}$ is the major mediator of $\mathrm{E}_{2}$ inhibition. This idea was confirmed by the observation that $\mathrm{E}_{2}$-inhibited the CAT activity of the construct, $\mathrm{p} 5^{\prime} \mathrm{B}$.CAT, but not that of
p5'A.CAT, p5'S.CAT, p5'S2.CAT or p5'S3.CAT. As expected, the control template, $\mathrm{p5}^{\prime} \mathrm{A}$.CAT containing site A, a thyroid hormone receptor (TR) and/or a retinoic acid responsive element (Taylor et al. 1996b) was not affected by $\mathrm{E}_{2}$. Although ER can bind to L-tri-iodothyronine response elements (TREs) and TRs bind to EREs, they do not transactivate the genes involved (Dellovade et al. 1996). Indeed, bacterially-expressed TR1 binds to ERE and hER $\alpha$ binds to TRE (data not shown, and Klinge et al. 1997), but clearly ER does not affect the activity of the A-site (p5'A.CAT, Fig. 2).

Our data also show that site $\mathrm{S}$ is not an ERE, because $E_{2}$ failed to affect the CAT activity of constructs containing a monomer, dimer or trimer of site $\mathrm{S}$ (Fig. 2). In addition, site $\mathrm{S}$ must be present for site $\mathrm{B}$ to be fully active, as the activity of a construct containing only the B-element, p5'B.CAT, was inhibited to a lesser extent than that of pSB.CAT, which contained both sites $\mathrm{S}$ and $\mathrm{B}$ (Fig. 2). These data add further support to the idea that site $\mathrm{S}$ is an amplifier sequence, as previously reported in the response of apo AI to glucocorticoid (Taylor et al. 1996a). At present, the trans-acting factors that may possibly bind to site $\mathrm{S}$ include Egr-1 and PEA-3 (Nerlov et al. 1992, Kilbourne et al. 1995) - developmental genes that are regulated by $\mathrm{E}_{2}$ in vitro (Lockwood et al. 1998, Pratt et al. 1998). There are other developmental genes, such as the homeobox gene family member proteins Hox a10 and Hox a11, which are also regulated in an $\mathrm{E}_{2}$-dependent manner (Ma et al. 1998). Although the responsive elements for the Hox family of transcription factors are not known, it is possible that Hox genes might interact with the apo AI promoter, and we speculate that a cascade of transcriptional factors and elements are involved in some of the actions of $\mathrm{E}_{2}$ on rat apo AI promoter repression. Furthermore, trans-acting factors that bind to adjacent cis-acting elements - HNF-4, ARP-1, and others - may play a role in the inhibitory effect of $\mathrm{E}_{2}$ through protein-protein interactions (Harnish et al. 1998, Hargrove et al. 1999).

The results of the EMSA studies suggest that the inhibitory effect of $\mathrm{E}_{2}$ on apo $A I$ transcription does not require binding of $h E R \alpha$ to either site $\mathrm{S}$ or site B. As expected, hER $\alpha$ binds to radiolabelled ERE (Fig. 3) and the formation of this complex is inhibited by unlabelled ERE. However, neither excess site $\mathrm{S}$ nor site $\mathrm{B}$ sequences are effective in displacing hER $\alpha$ from the radiolabelled probe. In addition, the converse experiment of hER $\alpha$ added to radiolabelled site $\mathrm{S}$ or site $\mathrm{B}$ produced no visible protein-DNA complexes (data not shown). These observations indicate that $\mathrm{hER} \alpha$ does not directly 
bind to site $\mathrm{S}$ or site $\mathrm{B}$ and $\mathrm{ER}$ probably decreases apo $A I$ transcription via an indirect mechanism.

The preceding observations prompted us to search for a potential mechanism using EMSA. If ER does not transmit the inhibitory effects of $E_{2}$ directly by binding to apo AI site $\mathrm{B}$, then what does? Nuclear extracts from $\mathrm{E}_{2}$-treated $\mathrm{HuH}-7$ cells had no effect on protein binding to radiolabelled site $\mathrm{S}$, but did decrease nucleoprotein binding to site $\mathrm{B}$ (Fig. 3). This finding suggests that loss of hepatonuclear protein binding to apo AI site $\mathrm{B}$ is responsible for the observed decreased in apo $A I$ transcription.

Site B contains two HNF-3 motifs (Fig. 4) that bind HNF-3 (Harnish et al. 1994). Constructs containing a mutation or deletion of either HNF-3 motif were no longer responsive to $\mathrm{E}_{2}$ (Fig. 4). These data are qualitatively similar to those from previous studies in which removal of the HNF-3 motifs from site B caused the loss of basal promoter activity (Harnish et al. 1994) and stimulated response to dexamethasone (Taylor et al. 1996a). The present observations show that both HNF-3 motifs are required by the promoter to maintain full responsiveness to $\mathrm{ER}$ and $\mathrm{E}_{2}$. It is conceivable that $\mathrm{E}_{2}$ influences the activity, abundance, or both, of HNF-3 isoforms (Lai et al. 1993, Harnish et al. 1998) or HNF-3-like proteins (Jacquemin et al. 1999) to transmit its effect on site B. This hypothesis also suggests that the HNF-3 isoforms or HNF-3like proteins would have opposing activities on apo $A I$ transcription via site $\mathrm{B}$. Indeed, HNF-6 (an HNF-3-like transcription factor) has recently been shown to inhibit HNF-3 trans-activation in a gender-specific manner (Lahuna et al. 1997).

The literature provides a confusing picture of the effect of $E_{2}$ in experimental animals when compared with that in humans, with the species and strain of experimental animal being of utmost importance. Our studies on serum protein concentrations showed that administration of $\mathrm{E}_{2}$ to female and male Sprague-Dawley rats increased and decreased serum apo AI concentrations respectively (Fig. 5). These observations negate our original hypothesis that the beneficial effect of $\mathrm{E}_{2}$ on apo AI serum concentrations in females would also be observed in males. In physiological doses, $\mathrm{E}_{2}$ had no significant effect on serum apo AI concentrations in male rats (data not shown). These data are consistent with the findings of a number of studies, showing either that male rats do not respond to administration of $E_{2}$, or that it decreases their apo AI secretion rate (Weinstein et al. 1986, Srivastava et al. 1993, 1997, Zou \& Ing 1998).

In some, but not all, studies transcription of apo $A I$ was shown to be unaffected, and the main effect of $\mathrm{E}_{2}$ occurred through gene translation (Srivastava et al. 1997). However, these data are not consistent with other data showing that $17 \beta$-ethinyl oestradiol in male rats increased apo AI concentrations (Seishima et al. 1991). In the present study, we used intact animals to measure serum apo AI and used high doses of $\mathrm{E}_{2}$. Perhaps this combination could explain the discrepancy between the findings presented here and those of others that involved castrated animals, smaller doses of $\mathrm{E}_{2}$, measured plasma apo AI concentrations or used alternative $\mathrm{E}_{2}$ formulations or routes of administration. As reporter assays may be more sensitive than in vivo studies because of ligand availability, we decided to increase the dose of $\mathrm{E}_{2}$ to a pharmacological value that simulates the concentrations of $\mathrm{E}_{2}$ in a pregnant woman (Check 1999). Our data suggest that supraphysiological doses of $\mathrm{E}_{2}$ in the male rat decrease the transcription of apo $A I$, in keeping with the findings of some animal studies (Weinstein et al. 1986, Srivastava et al. 1993, Zou \& Ing 1998). If decreased translation of apo AI mRNA is the main mechanism of decreased apo AI serum protein concentrations in rats (Srivastava et al. 1997), transcriptional rates and steady-state-levels of apo AI mRNA would presumably remain constant.

It is clear from our western and northern blot analyses of apo AI protein and hepatic RNA that $\mathrm{E}_{2}$ decreases both the abundance of apo AI protein in serum and mRNA in the liver of treated male rats. Furthermore, nuclear 'run-on' experiments show that the effects of $\mathrm{E}_{2}$ on apo $A I$ gene expression arise from its ability to inhibit transcription of the gene in hepatic nuclei of hormone-treated male rats. The $55 \%$ reduction in transcription rate is similar to the $70 \%$ reduction in mRNA and $60 \%$ reduction in serum protein concentrations. Although we have observed a good correlation between decreased $a p o$ AI transcription rates, steady-state mRNA and secreted protein concentrations, we cannot rule out that $\mathrm{E}_{2}$ could still exert a major effect on apo $A I$ translation. Indeed, this may explain the differential effect of $E_{2}$ in the male and female rats used in the present study. First, the relative concentrations of apo AI in male and female serum were different: males had significantly greater amounts of apo $\mathrm{AI} / \mu \mathrm{g}$ total serum protein. Secondly, in male rat hepatocytes, high doses of $\mathrm{E}_{2}$ decrease apo $A I$ transcription, but the hormone may also alter the expression of other proteins involved in the secretion or processing of apo AI. In the female rat hepatocyte, high doses of $\mathrm{E}_{2}$ also decrease apo $A I$ transcription, but the hormone may increase the activity of proteins involved in apo AI secretion and processing. This might lead to the observed gender differences in response to high-dose $\mathrm{E}_{2}$. In addition, 
$\mathrm{E}_{2}$ increases the expression of hepatic LDL receptor and lipoprotein lipase, which could increase the availability of re-circulated apo AI within the hepatocyte, and in turn may have an inhibitory effect on apo $A I$ transcription via altered translation, as a result of apo $\mathrm{AI} /$ lipoprotein recycling events (Song et al. 1998).

The findings summarized above show that, in contrast to females, male rats treated with low-dose $\mathrm{E}_{2}$ do not have the expected increases in the serum concentration of apo AI; furthermore, males treated with high doses of $E_{2}$ show decreased serum apo AI concentrations. These results support the idea that $\mathrm{E}_{2}$ has a detrimental effect on lipid metabolism in the male (Kalin \& Zumoff 1990) and are consistent with a recent report in which male rats treated with $17 \beta$-ethinyl oestradiol had undetectable apo AI (Landschultz et al. 1996). This information helps to explain the observations made in clinical studies (Fortin et al. 1984, Henriksson et al. 1987), in which the use of exogenous $\mathrm{E}_{2}$ to prevent further myocardial infarctions had the opposite effect, and actually enhanced CVD risk in males. A decrease in apo $A I$ expression may not be the only factor involved in the increased CVD risk in $\mathrm{E}_{2}$-treated males, because $\mathrm{E}_{2}$ has a number of additional effects on the progression of CVD. For example, $\mathrm{E}_{2}$ has potent thrombotic activity, and increases prostacyclin and prostaglandin secretion in the vasculature, but decreases intima thickening (Chang et al. 1980, Gisclard et al. 1988, Iafrati et al. 1997).

One could postulate that, as $\mathrm{E}_{2}$ decreases apo $\mathrm{AI}$ in male Sprague-Dawley rats, the hormone would have a similar effect in the human male and, therefore, the use of $\mathrm{E}_{2}$ in men would be contraindicated. It could be argued that male exposure to $\mathrm{E}_{2}$ is easily avoided, but oestrogens are commonly used in two clinical settings: the treatment of prostate cancer, and feminization during sex-change procedures. In addition, men are constantly exposed to environmental oestrogens that are believed to cause male infertility (Sonnenschein \& Soto 1998). The information arising from the current study is therefore of significant clinical relevance.

Our findings support previous reports that $\mathrm{E}_{2}$ has a detrimental effect on male health and actually enhances the risk of CVD, possibly by decreasing the concentrations of apo AI. Although the mechanism by which $\mathrm{E}_{2}$ increases apo AI concentrations in females but decreases it in males is not yet known, the data presented here help us to understand a fundamental aspect of apo AI gene expression. These data will be useful in the development of strategies to reduce the hypercholesterolaemic component of CVD. For example, because $\mathrm{E}_{2}$ decreases male apo $\mathrm{AI}$, a specific antioestrogen treatment that inhibits the effect of $\mathrm{E}_{2}$ on hepatic apo $A I$ expression might have a beneficial effect on CVD risk in the male.

\section{ACKNOWLEDGEMENTS}

Funding for this project was provided by the Heart and Stroke Foundation of Canada and Medical Research Council of Canada (MRC). N C W W is the recipient of Scientist awards from the MRC and Alberta Heritage Foundation for Medical Research.

The authors wish to thank Mrs J Forden for excellent technical assistance and Dr C K Krekowski, University of Calgary, for the gift of human rRNA cDNA.

\section{REFERENCES}

Ausubel FM, Brent R, Kingston RE, Moore DD, Seidman JG, Smith JA \& Struhl K (Eds) 1995 Unit 12.1 DNA-protein Interactions. In Current Protocols in Molecular Biology, pp $12 \cdot 1 \cdot 1-12 \cdot 1 \cdot 3$. New York: John Wiley \& Sons.

Barrett-Connor E \& Bush TL 1991 Estrogen and coronary heart disease in women. Fournal of the American Medical Association 265 1861-1867.

Barter PJ \& Rye KA 1996 High density lipoproteins and coronary heart disease. Atherosclerosis 121 1-12.

Bindal RD, Carlson KE, Katzenellenbogen BS \&

Katzenellenbogen JA 1988 Lipophilic impurities, not phenolsulfonphthalein, account for the estrogenic activity in commercial preparations of phenol red. Fournal of Steroid Biochemistry 31 287-293.

Bland M 1990 An Introduction to Medical Statistics. Oxford: Oxford University Press.

Bush TL 1990 The epidemiology of cardiovascular disease in postmenopausal women. Annals of the New York Academy of Sciences 592 263-271.

Bush TL, Barrett-Connor E, Cowan LD, Criqui MH, Wallace RB, Suchindran CM, Tyroler HA \& Rifkind BM 1987 Cardiovascular mortality and noncontraceptive use of estrogen in women: results from the Lipid Research Clinics Program Follow-up Study. Circulation 75 1102-1109.

Cerillo G, Rees A, Manchanda N, Reilly C, Brogan I, White A \& Needham M 1998 The estrogen receptor regulates NFKB and AP-1 activity in a cell-specific manner. Fournal of Steroid Biochemistry and Molecular Biology 67 79-88.

Chan J, Nakabyashi H \& Wong NCW 1993 HNF-4 increases activity of the rat apo AI gene. Nucleic Acids Research 21 1205-1211.

Chang WC, Nakao J, Orimo H \& Murato SI 1980 Stimulation of prostacyclin biosynthetic activity by estradiol in rat aorta smooth muscle cell in culture. Biochimica et Biophysica Acta 619 107-118.

Check JH 1999 Low and high responders - at what levels of serum estradiol do things start to get fuzzy? Fertility and Sterility 71 582-583.

Dellovade TL, Zhu YS, Krey L \& Pfaff DW 1996 Thyroid hormone and estrogen interact to regulate behaviour. PNAS 93 12581-12586.

Fangman RJ \& Hellwig CA 1947 Histology of coronary arteries in newborn infants. American Fournal of Pathology 23 901-902. 
Farhat MY, Lavigne MC \& Ramwell PW 1996 The vascular protective effects of estrogen. FASEB Fournal 10 615-624.

Fortin CJ, Klein T, Messmore HL \& O’Connell JB 1984 Myocardial infarction and severe thromboembolic complications. As seen in an estrogen-dependent transsexual. Archives of Internal Medicine 144 1082-1083.

Gisclard V, Miller VM \& Vanhoutte PM 1988 Effect of 17 beta-estradiol on endothelium-dependent responses in the rabbit. Fournal of Pharmacology and Experimental Therapeutics 224 19-22.

Glazer G 1991 Atherogenic effects of anabolic steroids on serum lipid levels: a literature review. Archives of Internal Medicine 151 1925-1933.

Hargrove GM, Junco A \& Wong NCW 1999 Hormonal regulation of apolipoprotein AI. Fournal of Molecular Endocrinology 22 103-111.

Harnish DC, Malik S \& Karathanasis SK 1994 Activation of apolipoprotein A-I gene transcription by the liver-enriched factor HNF-3. Fournal of Biological Chemistry 269 28220-28226.

Harnish DC, Evans MJ, Scicchitano MS, Bhat RA \& Karathanasis SK 1998 Estrogen regulation of the apolipoprotein AI gene promoter through transcription cofactor sharing. Fournal of Biological Chemistry 273 9270-9278.

Henriksson P, Linde B \& Edhag O 1987 Deleterious effects of low-dose oestrogen therapy on coronary status in patients with prostatic cancer. European Heart fournal 8 779-784.

Iafrati MD, Karas RH, Aronovitz M, Kim S, Sullivan TR Jr, Lubahn DB, O'Donnell TF Jr, Korach KS \& Mendelsohn ME 1997 Estrogen inhibits the vascular injury response in estrogen receptor-deficient mice. Nature Medicine 3 545-548.

Jacquemin P, Lannoy VJ, Rousseau GG \& Lemaigre FP 1999 OC-2 a novel mammal member of the ONECUT class of homeodomain transcription factors whose function in liver partially overlaps with that of hepatocyte nuclear factor-6. Fournal of Biological Chemistry 274 2665-2671.

Kalin MF \& Zumoff B 1990 Sex hormones and coronary disease: a review of the clinical studies. Steroids 55 330-352.

Kashyap ML 1998 Mechanistic studies of high-density lipoproteins. American Fournal of Cardiology 82 42U-48U.

Kilbourne EJ, Widom R, Harnish DC, Malik S \& Karathanasis SK 1995 Involvement of early growth response factor Egr-1 in apolipoprotein A-I gene transcription. Fournal of Biological Chemistry 270 7004-7010.

Klaiber EL, Broverman DM \& Dalen JE 1984 Serum estradiol levels in male cigarette smokers. American Fournal of Medicine 77 858-862.

Klinge CM, Bodenner DL, Desai D, Niles RM \& Traish AM 1997 Binding of type II nuclear receptors and estrogen receptor to full and half-site estrogen response elements in vitro. Nucleic Acids Research 25 1903-1912.

Lahuna O, Fernandez L, Karlsson H, Maiter D, Lemaigre FP, Rousseau GG, Gustafsson J-A \& Mode A 1997 Expression of hepatocyte nuclear factor 6 in rat liver is sex-dependent and regulated by growth hormone. PNAS 94 12309-12313.

Lai E, Clark KL, Burley SK \& Darnell JE Jr 1993 Hepatocyte nuclear factor $3 /$ forkhead or 'winged helix' proteins: a family of transcription factors of diverse biologic function. PNAS 90 10421-10423.

Landschulz KT, Pathak RK, Rigotti A, Kreiger M \& Hobbs HH 1996 Regulation of scavenger receptor, class B, type I, a high density lipoprotein receptor, in liver and steroidogenic tissues of the rat. Fournal of Clinical Investigations $\mathbf{9 8}$ 984-995.

Lockwood CJ, Krikun G, Hausknecht VA, Papp C \& Schatz F 1998 Matrix metalloproteinase and matrix metalloproteinase inhibitor expression in endometrial stromal cells during progestin-initiated decidualization and menstruation-related progestin withdrawal. Endocrinology 139 4607-4613.

Ma L, Benson GV, Lim H, Dey SK \& Maas RL 1998 Abdominal B (AbdB) Hoxa genes: regulation in adult uterus by estrogen and progesterone and repression in mullerian duct by the synthetic estrogen diethylstilbestrol (DES). Developmental Biology 197 141-154.

McCarthy TL, Ji C, Shu H, Casinghino S, Crothers K, Rotwein P \& Centrella M 1997 17ß-Estradiol potently suppresses cAMP-induced insulin-like growth factor-1 gene activation in primary rat osteoblast cultures. Fournal of Biological Chemistry 272 18132-18139.

Maniatis T, Fritsch EF \& Sambrooke J 1983 Molecular Cloning: a Laboratory Manual, pp 464-465. New York: Cold Spring Harbor Laboratory Press.

Marmorston J, Moore FJ, Kuzma OT, Magidson O \& Weiner J 1960 Effect of Premarin on survival of men with myocardial infarction. Proceedings of the Society for Experimental Biology and Medicine 110 400-408.

Morgan MY 1982 Sex and alcohol. British Medical Bulletin 38 $43-52$.

Nakabyashi H, Watanabe K, Saito A, Otsuru O, Sawadaishi K \& Tamaoki T 1989 Transcriptional regulation of alphafetoprotein expression by dexamethasone in human hepatoma cells. Fournal of Biological Chemistry 264 266-271.

Nerlov C, De Cesare D, Pergola F, Caracciolo A, Blasi F, Johnsen M \& Verde P 1992 A regulatory element that mediates co-operation between a PEA3-AP-1 element and an AP-1 site is required for phorbol ester induction of urokinase enhancer activity in HepG2 hepatoma cells. EMBO fournal $114573-4582$

Neufeld HN, Wagenvoort CA \& Edwards JE 1962 Coronary arteries in fetuses, infants, juveniles and young adults. Laboratory Investigations 11 827-844.

O'Kane MJ, Lynch PL, Callender ME \& Trimble ER 1997 Abnormalities of serum apo AI containing lipoprotein particles in patients with primary bilary cirrhosis. Atherosclerosis 131 203-210.

Phillips GB 1984 Evidence for hyperestrogenemia as the link between diabetes mellitus and myocardial infarction. American Fournal of Medicine 76 1041-1048.

Pratt MA, Satkunaratnam A \& Novosad DM 1998 Estrogen activates raf-1 kinase and induces expression of Egr-1 in MCF7 breast cancer cells. Molecular and Cellular Biochemistry 189 119-125.

Reese JC \& Katzenellenbogen BS 1991 Differential DNAbinding abilities of estrogen receptor occupied with two classes of antiestrogens: studies using human estrogen receptor overexpressed in mammalian cells. Nucleic Acids Research 19 6595-6602.

Romney JS, Chan J, Carr FE, Mooradian AD \& Wong NCW 1992 Identification of the thyroid hormone-responsive messenger RNA spot 11 as apolipoprotein-AI messenger RNA and effects of the hormone on the promoter. Molecular Endocrinology 6 943-950.

Ruebner BH, Miyai K \& Abbey H 1961 The low incidence of myocardial infarction in hepatic cirrhosis: a statistical artifact? Lancet 2 1435-1436.

Sakurai T, Tosaka A, Yamada T, Kuwahara T \& Masubuchi K 1978 Childhood coronary sclerosis. Acta Pathologica faponica 28 41-52.

Sambrooke J, Fritsch EF \& Maniatis T 1989 Molecular Cloning: a Laboratory Manual, edn 2, pp 7·37-7·52. Plainview, NY: Cold Spring Harbor Laboratory Press.

Sanders MM \& McKnight GS 1988 Positive and negative regulatory elements control the steroid-responsive ovalbumin promoter. Biochemistry 27 6550-6557. 
Seishima M, Bisgaier CL, Davies SL \& Glickman RM 1991 Regulation of hepatic apolipoprotein synthesis in the $17 \alpha$ ethinyl estradiol-treated rat. Fournal of Lipid Research 32 941-951.

Shewmon DA 1994 Lipids, atherosclerosis, and the postmenopausal woman: a clinical perspective. Obstetrics and Gynecology Clinics of North America 21 337-355.

Song W, Chen J \& Redinger RN 1998 Apolipoprotein A-I complexed with phospholipid promotes hepatic lipoprotein and apolipoprotein secretion in the perfused hamster liver. Fournal of Investigative Medicine 46 460-469.

Sonnenschein C \& Soto AM 1998 An updated review of environmental estrogen and androgen mimics and antagonists. Fournal of Steroid Biochemistry and Molecular Biology 65 143-150.

Srivastava RAK, Baumann D \& Schonfeld G 1993 In vivo regulation of low-density lipoprotein receptors by estrogen differs at the post-transcriptional level in rat and mouse. European Fournal of Biochemistry 216 527-538.

Srivastava RAK, Krul ES, Lin RC \& Schonfeld G 1997 Regulation of lipoprotein metabolism by estrogen in inbred strains of mice occurs primarily by posttranscriptional mechanisms. Molecular and Cellular Biochemistry 173 161-168.

Staels B \& Auwerx J 1998 Regulation of apo A-I gene expression by fibrates. Atherosclerosis 137 S19-S23.

Stampfer MJ \& Colditz GA 1991 Estrogen replacement therapy and coronary heart disease: a quantitative assessment of the epidemiologic evidence. Preventative Medicine 20 $47-63$.

Sullivan JM, van der Zwaag R, Hughes JP, Maddock V, Kroetz FW, Ramanathan KB \& Mirvis DM 1990 Estrogen replacement and coronary heart disease: effect of survival in post menopausal women. Archives of Internal Medicine $\mathbf{1 5 0}$ $2557-2562$.

Sylvester JE, Whiteman DA, Podolsky R, Pozsgay JM, Respess J \& Schmickel RD 1986 The human ribosomal RNA genes: structure and organization of the complete repeating unit. Human Genetics 73 193-198.

Taylor AH, Raymond J, Dionne JM, Romney J, Chan J, Lawless DE, Wanke IE \& Wong NCW $1996 a$

Glucocorticoid increases rat apolipoprotein A-I promoter activity. Fournal of Lipid Research 37 2232-2243.

Taylor AH, Wishart P, Lawless DE, Raymond J \& Wong NCW $1996 b$ Identification of functional positive and negative thyroid hormone-responsive elements in the rat apolipoprotein A-I promoter. Biochemistry 35 8281-8288.

Vu-Dac N, Gervois P, Grotzinger T, De Vos P, Schoonjans K, Fruchart J-C, Aurwerx J, Mariani J, Tedgui A \& Staels B 1997 Transcriptional regulation of apolipoprotein A-I gene expression by the nuclear receptor ROR $\alpha$. Fournal of Biological Chemistry 272 22401-22404.

Walsh BW, Schiff I, Rosner B, Greenberg L, Ravnikar V \& Sacks FM 1991 Effects of postmenopausal estrogen replacement on the concentrations and metabolism of plasma lipoproteins. New England Fournal of Medicine 325 1196-1204.

Weinstein I, Wilcox HG \& Heimberg M 1986 Effects of high-dose ethinyl estradiol on serum concentrations and hepatic secretion of the very-low-density lipoprotein, triacylglycerol, cholesterol, and apolipoprotein A-I in the rat. Biochimica et Biophysica Acta 876 450-459.

Xie W, Duan R \& Safe S 1999 Estrogen induces adenosine deaminase gene expression in MCF-7 human breast cancer cells: role of estrogen receptor-Sp1 interactions. Endocrinology 140 219-227.

Zou K \& Ing NH 1998 Oestradiol up-regulates oestrogen receptor, cyclophilin, and glyceraldehyde phosphate dehydrogenase copy $1 \mathrm{mRNA}$ concentrations in endometrium, but down-regulates them in the liver. Fournal of Steroid Biochemistry and Molecular Biology 64 231-237.

REVISED MANUSCRIPT RECEIVED 26 April 2000 